\title{
Recent legalization of cannabis use: effects on sleep, health, and workplace safety
}

\section{Nicole P Bowles \\ Maya $X$ Herzig \\ Steven A Shea}

Oregon Institute of Occupational Health Sciences, Oregon Health \& Science University, Portland, OR, USA
Correspondence: Steven A Shea Oregon Institute of Occupational Health Sciences, Oregon Health \& Science University, 3I8I SW Sam Jackson Park Road, Portland, OR 97239, USA

Email sheast@ohsu.edu
This article was published in the following Dove Press journal:

Nature and Science of Sleep

19 October 2017

Number of times this article has been viewed

The recent legalization of cannabis for medical and recreational use in many states in the United States and internationally ${ }^{4,5}$ has resulted in a decrease in stigma and of perceived risk of cannabis use, more frequent use of cannabis, use of higher potency cannabis products, and increased dependence on cannabis use. ${ }^{6-8}$ Cannabis sativa and its derivatives are often used for improved sleep and relaxation; characteristics originally attributed to Indian hemp in the nineteenth century. ${ }^{1-3}$ Cannabis alters the sleep-wake cycle, increases the production of melatonin, and can inhibit the arousal system by activating cannabinoid type $1\left(\mathrm{CB}_{1}\right)$ receptors in the basal forebrain and other wakepromoting centers. ${ }^{9-12}$ Investigations have shown that the major psychoactive compound in cannabis, $\Delta^{9}$-tetrahydrocannabinol (THC), can decrease sleep onset latency in naïve users or at low doses in experienced users (eg, $70 \mathrm{mg} /$ day); however, higher doses in experienced users increased sleep latency and wake after sleep onset. ${ }^{9,13,14}$ Indeed, frequent cannabis users ( $\geq 5$ uses/week for 3 months and lifetime use $\geq 2$ years) are reported to have shorter total sleep duration, less slow wave sleep, worse sleep efficiency, and longer sleep onset compared to controls. ${ }^{15}$ The contrasting benefits of THC exposure may represent the biphasic influence of $\mathrm{THC}$ on $\mathrm{CB}_{1}$ receptors whereby acute use causes more activation of $\mathrm{CB}_{1}$ receptors and tendency toward sleep, but long-term use results in desensitization of the $\mathrm{CB}_{1}$ receptor and decreased downstream signaling.

Any study of the effects of cannabis on sleep should take into consideration the route of ingestion, strain of cannabis, dose, prior cannabis exposure, and the method to quantify sleep. In this regard, it is noteworthy that over the last two decades, the average THC concentration has tripled and the products available for sale contain much higher concentrations than those that were generally available for laboratory studies. ${ }^{16-19}$ In addition to THC, hundreds of other compounds exist in cannabis products such as the non-psychoactive cannabidiol, cannabinol, and terpenes, which can also impact sleep and wakefulness. ${ }^{9,12,20}$ Individuals who obtain cannabis at medical dispensaries or for recreational use are also more likely to use alternative ingestion methods including edibles, concentrates (eg, dabbing), or extracts applied topically as oils or balms. ${ }^{21-23}$ Studies on the impact of these ingestion methods are limited, and the health consequences specific to vaping and dabbing remain largely unknown. For example, absorption rate and bioavailability are dependent upon the route of ingestion. ${ }^{24}$ Although the initial psychoactive effects of digested cannabis take longer to be felt, these effects are longer lasting compared to inhaled cannabis, which can 
often lead to overconsumption of cannabis compounds. ${ }^{25}$ The effects of cannabis are also dependent on weight, metabolism, gender, and prior digested meals. ${ }^{24,25}$ Given these complexities, prior laboratory studies are unlikely to reflect the users' naturalistic experiences of sleep and of cannabis use in the present day.

The greatest body of medical cannabis research centers around pain management, while sleep appears sparingly as an ancillary result of these studies. In a randomized trial of 21 patients with chronic pain, significant improvements in sleep onset and sleep maintenance were found with a thrice-daily controlled administration of smoked cannabis (9.4\% THC) compared to a placebo control. ${ }^{18}$ This suggests that the use of cannabis in place of opioids for pain management could be beneficial, but we are not aware of a head-to-head comparison of opioids versus cannabis with pain and sleep as outcomes. However, there may be some indirect evidence such as the 2014 mean annual opioid overdose mortality rates, which were $24.9 \%$ lower in states with legalized medical cannabis than in those without. ${ }^{26}$ On an individual basis, patients using both cannabis and prescription pain medication have rated the efficacy of cannabis better for pain management and indicated improved sleep, quality of life, and a preference to reduce reliance on pain medication. ${ }^{27,28}$

The legalization of cannabis use inevitably brings concerns regarding the possibility that cannabis might impair workplace performance and safety. Results from the 2015 National Survey on Drug Use and Health indicate that more than $13 \%$ of adults used cannabis in the past year and over $8 \%$ within the last month. ${ }^{29}$ This is consistent with a 2006 report of pastyear cannabis use in $11 \%$ and past-month use in $5 \%$ of the surveyed workforce with more than $3 \%$ of that population also reporting cannabis use at work during the past 12 months. ${ }^{30}$ Concerns about workers' cannabis use range from acute physical and decision-making impairments to long-term cognitive deficits. ${ }^{31,32}$ Occupational health guidelines are emerging to keep pace with increased cannabis legalization. ${ }^{32,33}$ However, the evidence supporting these recommendations is as sparse and as inconsistent as the sleep data. In a recent study of simulated shift work, smoked cannabis in frequent users $(3.6 \%$ THC) was found to lessen the impairments in attention and performance during a night shift schedule. ${ }^{34}$ While there are few studies examining the risk of accidents in the workplace after exposure to cannabis, motor vehicle operation can serve as a model for performance of tasks involving safety. Individual user's opinions on cannabis-intoxicated driving vary wildly, as does the quantitative data. ${ }^{35}$ For example, one group found significant increases in vehicle crash fatalities in California after decriminalization of cannabis use in 2012; however, a more recent study found no significant differences in the three years after recreational legalization in Colorado and Washington. ${ }^{36,37}$ In a meta-analysis of observational studies from 1982 to 2015, THC intoxication detected via blood, saliva, or urine tests was associated with a "low to medium magnitude" increase in motor vehicle crash risk. ${ }^{38}$ On the other hand, a case-control study of workplace accidents found no significant difference in risk between workers who tested positive for cannabis on a urine drug test versus a random sample of workers. ${ }^{39}$ A problem with any such study is that $\mathrm{THC}$ is a fat-soluble compound and remains in the body and is detectable in urine for many days after the other effects have worn off. This limitation of not being able to detect and distinguish recent cannabis use via biological samples has likely contributed to the variability of empirical data and inconclusive or unsatisfactory recommendations. The growing workplace concerns demand targeted investigation to educate both employers and employees of dose-response effects of cannabis and daytime sleepiness, and to better inform workplace safety and health guidelines.

The future of cannabis research provides many avenues for discovery. While pain reduction and sleep promotion seem promising applications for cannabis use, there are still many unknowns. Broadly, there is a need for increased research to increase potential benefits while reducing harm. Specifically, there is a need for investigations of naturalistic cannabis use, its effects on sleep, and implications for safety. These studies could inform educational campaigns to promote healthy consumption of cannabis and evidence-based guidelines for public health and workplace safety.

\section{Disclosure}

The authors report no conflicts of interest in this work.

\section{References}

1. Mechoulam R, Gaoni Y. A total synthesis of D1-Delta-1-tetrahydrocannabinol, the active constituent of hashish. J Am Chem Soc. 1965;87: 3273-3275.

2. Walsh Z, Callaway R, Belle-Isle L, et al. Cannabis for therapeutic purposes: patient characteristics, access, and reasons for use. Int J Drug Policy. 2013;24(6):511-516.

3. Nunberg H, Kilmer B, Pacula RL, Burgdorf J. An analysis of applicants presenting to a medical marijuana specialty practice in California. $J$ Drug Policy Anal. 2011;4(1):1.

4. Goldsmith RS, Targino MC, Fanciullo GJ, et al. Medical marijuana in the workplace: challenges and management options for occupational physicians. J Occup Environ Med. 2015;57(5):518-525.

5. Kilmer B, Pacula RL. Understanding and learning from the diversification of cannabis supply laws. Addiction. 2017;112(7):1128-1135.

6. Kosterman R, Bailey JA, Guttmannova K, et al. Marijuana legalization and parents' attitudes, use, and parenting in Washington State. J Adolesc Health. 2016;59(4):450-456. 
7. Schuermeyer J, Salomonsen-Sautel S, Price RK, et al. Temporal trends in marijuana attitudes, availability and use in Colorado compared to nonmedical marijuana states: 2003-11. Drug Alcohol Depend. 2014;140: 145-155.

8. Cerdá M, Wall M, Keyes KM, Galea S, Hasin D. Medical marijuana laws in 50 states: investigating the relationship between state legalization of medical marijuana and marijuana use, abuse and dependence. Drug Alcohol Depend. 2012;120(1):22-27.

9. Nicholson AN, Turner C, Stone BM, Robson PJ. Effect of Delta9-tetrahydrocannabinol and cannabidiol on nocturnal sleep and early-morning behavior in young adults. J Clin Psychopharmacol. 2004;24(3):305-313.

10. Lissoni P, Resentini M, Mauri R, et al. Effects of tetrahydrocannabinol on melatonin secretion in man. Horm Metab Res. 1986;18(1):77-78.

11. Murillo-Rodriguez E, Blanco-Centurion C, Sanchez C, Piomelli D, Shiromani PJ. Anandamide enhances extracellular levels of adenosine and induces sleep: an in vivo microdialysis study. Sleep. 2003;26(8):943-947.

12. Murillo-Rodriguez E, Millán-Aldaco D, Palomero-Rivero M, Mechoulam R, Drucker-Colín R. Cannabidiol, a constituent of Cannabis sativa, modulates sleep in rats. FEBS Lett. 2006;580(18):4337-4345.

13. Tassinari CA, Ambrosetto G, Peraita-Adrado MR, Gastuat H. The neuropsychiatric syndrome of $\delta 9$-tetrahydrocannabinol and cannabis intoxication in naive subjects. Marihuana Med. 1999:649-664.

14. Feinberg I, Jones R, Walker J, Cavness C, Floyd T. Effects of marijuana extract and tetrahydrocannabinol on electroencephalographic sleep patterns. Clin Pharmacol Ther. 1976;19(6):782-794.

15. Bolla KI, Lesage SR, Gamaldo CE, et al. Sleep disturbance in heavy marijuana users. Sleep. 2008;31(6):901-908.

16. Smart R, Caulkins JP, Kilmer B, Davenport S, Midgette G. Variation in cannabis potency and prices in a newly legal market: evidence from 30 million cannabis sales in Washington state. Addiction. Epub 2017 May 27.

17. ElSohly MA, Mehmedic Z, Foster S, Gon C, Chandra S, Church JC Changes in cannabis potency over the last 2 decades (1995-2014): analysis of current data in the United States. Biol Psychiatry. 2016;79(7): 613-619.

18. Ware MA, Wang T, Shapiro S, et al. Smoked cannabis for chronic neuropathic pain: a randomized controlled trial. CMAJ. 2010;182(14): E694-E701.

19. Newmeyer MN, Swortwood MJ, Taylor ME, Abulseoud OA, Woodward TH, Huestis MA. Evaluation of divided attention psychophysical task performance and effects on pupil sizes following smoked, vaporized and oral cannabis administration. J Appl Toxicol. 2017;37(8):922-932.

20. Monti JM. Hypnoticlike effects of cannabidiol in the rat. Psychopharmacology (Berl). 1977;55(3):263-265.

21. Borodovsky JT, Crosier BS, Lee DC, Sargent JD, Budney AJ. Smoking, vaping, eating: Is legalization impacting the way people use cannabis? Int J Drug Policy. 2016;36:141-147.

22. Daniulaityte R, Lamy FR, Barratt M, et al. Characterizing marijuana concentrate users: a web-based survey. Drug Alcohol Depend. 2017;178:399-407.
23. Lankenau SE, Fedorova EV, Reed M, Schrager SM, Iverson E, Wong CF. Marijuana practices and patterns of use among young adult medical marijuana patients and non-patient marijuana users. Drug Alcohol Depend. 2017;170:181-188.

24. Borgelt LM, Franson KL, Nussbaum AM, Wang GS. The pharmacologic and clinical effects of medical cannabis. Pharmacotherapy. 2013;33(2):195-209.

25. Grotenhermen F. Pharmacokinetics and pharmacodynamics of cannabinoids. Clin Pharmacokinet. 2003;42(4):327-360.

26. Bachhuber MA, Saloner B, Cunningham CO, Barry CL. Medical cannabis laws and opioid analgesic overdose mortality in the United States, 1999-2010. JAMA Intern Med. 2014;174(10):1668-1673.

27. Haroutounian S, Ratz Y, Ginosar Y, et al. The effect of medicinal cannabis on pain and quality-of-life outcomes in chronic pain: a prospective open-label study. Clin J Pain. 2016;32(12):1036-1043.

28. Perron BE, Bohnert K, Perone AK, Bonn-Miller MO, Ilgen M. Use of prescription pain medications among medical cannabis patients: comparisons of pain levels, functioning, and patterns of alcohol and other drug use. J Stud Alcohol Drugs. 2015;76(3):406-413.

29. Center for Behavioral Health Statistics and Quality. Results from the 2015 National Survey on Drug Use and Health: Detailed Tables; 2016 Available from: http://www.samhsa.gov/data/. Accessed September 5 2017.

30. Frone MR. Prevalence and distribution of illicit drug use in the workforce and in the workplace: findings and implications from a U.S. National survey. J Appl Psychol. 2006;91(4):856-869.

31. Macdonald S, Hall W, Roman P, Stockwell T, Coghlan M, Nesvaag $\mathrm{S}$. Testing for cannabis in the work-place: a review of the evidence. Addiction. 2010;105(3):408-416.

32. Stringham C, Allard I, Knapp S, Minor M. Medical marijuana in the work place: keeping small business informed. Small Bus Inst J. 2017;13(1):16-29.

33. Canadian Centre for Occupational Health and Safety. Workplace Strategies: Risk of Impairment from Cannabis. Ottawa: Canadian Centre for Occupational Health and Safety; 2017.

34. Keith DR, Gunderson EW, Haney M, Foltin RW, Hart CL. Smoked marijuana attenuates performance and mood disruptions during simulated night shift work. Drug Alcohol Depend. 2017;178:534-543.

35. Cavazos-Rehg PA, Krauss MJ, Sowles SJ, Zewdie K, Bierut L. Operating a motor vehicle after marijuana use: perspectives from people who use high potency marijuana. Subst Abus. 2017:1-6.

36. Pollini RA, Romano E, Johnson MB, Lacey JH. The impact of marijuana decriminalization on California drivers. Drug Alcohol Depend. 2015;150:135-140.

37. Aydelotte JD, Brown LH, Luftman KM, et al. Crash fatality rates after recreational marijuana legalization in Washington and Colorado. Am J Public Health. 2017;107(8):1329-1331.

38. Rogeberg O, Elvik R. The effects of cannabis intoxication on motor vehicle collision revisited and revised. Addiction. 2016;111(8):1348-1359.

39. Price JW. Marijuana and workplace safety: an examination of urine drug tests. J Addict Dis. 2014;33(1):24-27.

Dove Medical Press encourages responsible, free and frank academic debate. The content of the Nature and Science of Sleep 'Editorial' section does not necessarily represent the views of Dove Medical Press, its officers, agents, employees, related entities or the Nature and Science of Sleep editors. While all reasonable steps have been taken to confirm the content of each Editorial, Dove Medical Press accepts no liability in respect of the content of any Editorial, nor is it responsible for the content and accuracy of any Editorial.

Nature and Science of Sleep

\section{Publish your work in this journal}

Nature and Science of Sleep is an international, peer-reviewed, open access journal covering all aspects of sleep science and sleep medicine, including the neurophysiology and functions of sleep, the genetics of sleep, sleep and society, biological rhythms, dreaming, sleep disorders and therapy, and strategies to optimize healthy sleep. The manuscript management system is completely online and includes a very quick and fair peer-review system, which is all easy to use. Visit http://www. dovepress.com/testimonials.php to read real quotes from published authors. 